\title{
Partial migration of a maraena whitefish Coregonus maraena population from the River Elbe, Germany
}

\author{
Marcel Gerson ${ }^{1, *}$, Jan Dierking ${ }^{2}$, Lasse Marohn ${ }^{3}$, Ralf Thiel $^{4}$, Andreas Klügel ${ }^{5}$, \\ Victoria Sarrazin ${ }^{4}$ \\ ${ }^{1}$ Private address: 53111 Bonn, Germany \\ ${ }^{2}$ Research Division Marine Ecology, GEOMAR Helmholtz Centre for Ocean Research Kiel, 24105 Kiel, Germany \\ ${ }^{3}$ Thünen Institute of Fisheries Ecology, 27572 Bremerhaven, Germany \\ ${ }^{4}$ Center of Natural History (CeNak), University of Hamburg, 20146 Hamburg, Germany \\ ${ }^{5}$ Department of Geosciences, University of Bremen, 28359 Bremen, Germany
}

\begin{abstract}
The maraena whitefish Coregonus maraena is a threatened anadromous species in the North Sea, which in the past was decimated to near extinction. Since the late 1980s, several re-establishment programs have been implemented in rivers draining into the North Sea, but the scientific basis for sustainable conservation measures is often lacking, since little is known about the biology of this species. In this study, otolith microchemistry of fish ranging from 24.6 to $58.4 \mathrm{~cm}$ in total length (median $31.3 \mathrm{~cm}, \mathrm{SD} 8.4 \mathrm{~cm}$ ) was used to characterize the migration behavior of a reintroduced population of maraena whitefish from the River Elbe, Germany. Our analyses revealed the presence of 3 different migration patterns: (1) one-time migration into high-salinity habitat (North Sea) within the first year of life $(29.6 \%),(2)$ multiple migrations between low- and high-salinity habitats starting in the first year of life (14.8\%) and (3) permanent residency within low-salinity habitats, a pattern displayed by the majority $(55.6 \%)$ of sampled individuals. Not only do these results reveal differential migration behavior, but they also indicate that permanent river residency is common in the River Elbe population of $C$. maraena. The role of the Elbe as both a feeding and a spawning habitat should thus be considered more explicitly in current conservation measures to support recovery of this species.
\end{abstract}

KEY WORDS: Migratory fish species · Conservation · Otolith microchemistry

\section{INTRODUCTION}

A major threat for diadromous fish species is habitat alteration, which includes physical and chemical barriers that block natural migration routes, but also causes the direct loss of freshwater habitat for spawning or nursery (de Groot 2002, Limburg \& Waldman 2009). Furthermore, as most diadromous species are of commercial importance, fishing is a contributing factor to the decline of many species (Limburg \& Waldman 2009). These threats apply to both anadromous species migrating

\footnotetext{
${ }^{*}$ Corresponding author: m.gerson@gmx.net
}

into rivers to spawn (e.g. salmonids), and to catadromous species migrating into the sea to spawn (e.g. eels).

The maraena whitefish Coregonus maraena is a salmonid species (Salmonidae) and belongs to the subfamily Coregoninae (Nelson et al. 2016). The Coregoninae is a diverse taxon from the northern hemisphere, which demonstrates considerable variation both among and within species regarding morphology and behavior, for instance in the number of gill rakers or the migration strategy (e.g. Hansen et al. 1999, Harris et al. 2012, Jacobsen et al. 2012).

(C) The authors 2021. Open Access under Creative Commons by Attribution Licence. Use, distribution and reproduction are unrestricted. Authors and original publication must be credited. 
In the majority of studies and in recent conservation efforts, the anadromous North Sea form of C. maraena, the subject of the present study, has been designated as North Sea houting C. oxyrinchus, e.g. in the Danish EU LIFE project running from 2005 to 2012 and the EU Habitats Directive (Council Directive 92/43/EEC of 21 May 1992 on the conservation of natural habitats and of wild fauna and flora). However, the nomenclature within the genus Coregonus has led to considerable discussion and confusion. Since the consideration of houting in the North Sea is not limited to the possibly extinct species C. oxyrinchus, but rather to the North Sea population of $C$. maraena (Bloch 1779) or a previously undescribed species (Kottelat \& Freyhof 2007), we use the scientific name C. maraena instead of C. oxyrinchus following Mehner et al. (2018). Whether whitefish populations from the North Sea should be considered a separate species from those in the Baltic Sea is still subject to scientific discussions (Dierking et al. 2014, L. F. Jensen et al. 2015, Mehner et al. 2018). However, there is evidence that the extant form of whitefish from the North Sea should be classified as a separate evolutionarily significant unit for conservation purposes, independent of the actual species status (Dierking et al. 2014).

In the North Sea, C. maraena was formerly common and widespread throughout the Wadden Sea region (Duncker \& Ladiges 1960, Jensen et al. 2003). In the $20^{\text {th }}$ century, anthropogenic activities such as river regulations including the building of dykes, groins and sluices, as well as pollution (Hansen et al. 1999, Kammerad 2001b, Jensen et al. 2003), caused migration barriers and habitat loss, including the deterioration or even elimination of spawning grounds (Grøn 1987, Kammerad 2001b) and consequently almost led to the extinction of C. maraena (Hansen et al. 1999, Jensen et al. 2003).

In the River Elbe drainage system, which includes one of the largest European estuaries (Pihl et al. 2002), C. maraena fisheries with annual yields of up to $23 \mathrm{t}$ were supported until the early $20^{\text {th }}$ century (Kammerad 2001a,b), but then the population collapsed due to reasons mentioned above and this species became locally extirpated. Similarly, other anadromous species have been negatively affected (e.g. Atlantic salmon Salmo salar, twaite shad Alosa fallax, river lamprey Lampetra fluviatilis) or have been locally extirpated, e.g. sturgeon Acipenser sturio and allis shad Alosa alosa (Thiel \& Thiel 2015). In the North Sea, only 2 small remnant populations of $C$. maraena persisted in the Danish rivers Vidå and Ribe $\AA$ (Jensen et al. 2003).
Currently, C. maraena is classified as 'Vulnerable' (VU A2cd) in the IUCN Red List (Freyhof 2011), and as 'threatened' and/or 'declining' by the Convention for the Protection of the Marine Environment of the North-East Atlantic (OSPAR Convention), and it is a priority species listed in Annexes II and IV of the Habitats Directive. This means that special areas of conservation are required for the conservation of the species, and the species is in need of strict protection (Svendsen et al. 2018).

The first programs for re-establishment of C. maraena in formerly inhabited rivers in the North Sea were set up for several Danish rivers and the German Eider-Treene river system in the late 1980s (Kammerad 2001b, Jensen et al. 2003, Jepsen et al. 2012), followed by the Rivers Elbe and Rhine (Kammerad 2001b, Borcherding et al. 2010, Dierking et al. 2014). Since 1997, the Elbe tributaries Seeve, Este, Oste, Luhe and Aue (Lühe) have each been stocked annually with 10 000-15 000 fingerlings of $C$. maraena (2-3 cm long) in spring, i.e. a few weeks after hatching in April (see www.schnaepel.de/). Nevertheless, natural reproduction in the River Elbe in the recent past has occurred only on a very low level (Thiel \& Thiel 2015). To date, these programs have relied heavily on stocking, as currently too little is known about the environmental improvements needed for a natural recovery of these populations (Svendsen et al. 2018). At present, habitat conditions generally considered important for diadromous species, such as water quality and passability, have improved in several rivers (de Groot \& Nijssen 1997, Borcherding et al. 2010), in principle paving a possible path to recovery in the future.

Investigations of $C$. maraena in the River Vidå showed that adult fish entered the river mostly in October and arrived at putative spawning areas in November (Hertz et al. 2019). Downstream migration started predominantly in December, and the fish entered the Wadden Sea in March and April (Jensen et al. 2018). Other studies confirm spawning migrations into the rivers in early winter (Jepsen et al. 2012) and a return to the sea in spring (Jensen et al. 2003). However, other studies suggest a certain degree of intraspecific flexibility, both in terms of onset of migration and time spent in the river after spawning (Jensen et al. 2018) as well as in terms of dispersal migration behavior, including non-migrating individuals and migrations at larger size and higher age (Borcherding et al. 2008). To date, no studies on the migration behavior of $C$. maraena have been carried out in the Elbe.

Otolith microchemistry has become an important tool for the identification of migratory behavior, par- 
ticularly for diadromous species (Walther \& Limburg 2012). The concentration of strontium (Sr) and barium (Ba) in ambient water, given as element:calcium (Ca) ratios, varies with water salinity; the $\mathrm{Sr}$ :Ca ratio is generally positively correlated and the $\mathrm{Ba}$ :Ca ratio is generally negatively correlated with increasing salinity (Tabouret et al. 2010). Accordingly, Sr:Ca ratios are usually negatively correlated to $\mathrm{Ba} \mathrm{Ca}$ ratios. These elements are incorporated into the calcium carbonate matrix of hard structures such as otoliths by substituting for calcium (Kalish 1990). As otoliths are chemically inert (Campana \& Neilson 1985), different concentrations of $\mathrm{Sr}$ and $\mathrm{Ba}$ in freshand saltwater are reflected in the chemical composition of all otolith growth zones just like spatial fingerprints. Element:Ca ratios measured along a transect from the nucleus-area to the edge of an otolith are therefore a suitable measure to reveal the migration history of diadromous fishes.

This study had the overarching goal to help close the knowledge gap with respect to habitat use and migration behavior of the C. maraena population in the River Elbe-Wadden Sea system. Specifically, our aims were (1) to characterize the use of low- versus highsalinity habitats (and thus migrations between the 2 habitats) of individuals from this population, (2) to assess the possible presence and prevalence of differences in migration behavior among individuals, and (3) to assess the role of possible underlying factors affecting migration behavior, such as ontogenetic changes and sex-specific differences. From an applied conservation perspective, this information can help resource managers to understand habitat requirements of this threatened species in the River ElbeWadden Sea system.

\section{MATERIALS AND METHODS}

\subsection{Study area}

The study area was located in the lower River Elbe between Hamburg and Cuxhaven in northern Germany (Fig. 1). The river section between Geesthacht and Cuxhaven, where the Elbe discharges into the North Sea, is tidal and exhibits a salinity gradient, ranging from almost 0 to around 32 PSU (Boehlich \& Strotmann 2008). Fishes from this lower section can freely migrate between freshwater and saltwater as there is no migration barrier.

\subsection{Sampling and otolith preparation}

We obtained 27 adult/subadult specimens of Coregonus maraena from bycatch of professional fisheries in the lower Elbe in June/July 2012 and February/ March 2013. Nine and 17 individuals were collected at 2 catch locations (Sites 1 and 2, respectively) in the freshwater section close to Hamburg, and 1 individual was caught in the polyhaline section (Site 3) of the Elbe close to Cuxhaven (Fig. 1). All fish were frozen after capture. One additional individual that was hatched and raised in a freshwater aquaculture farm

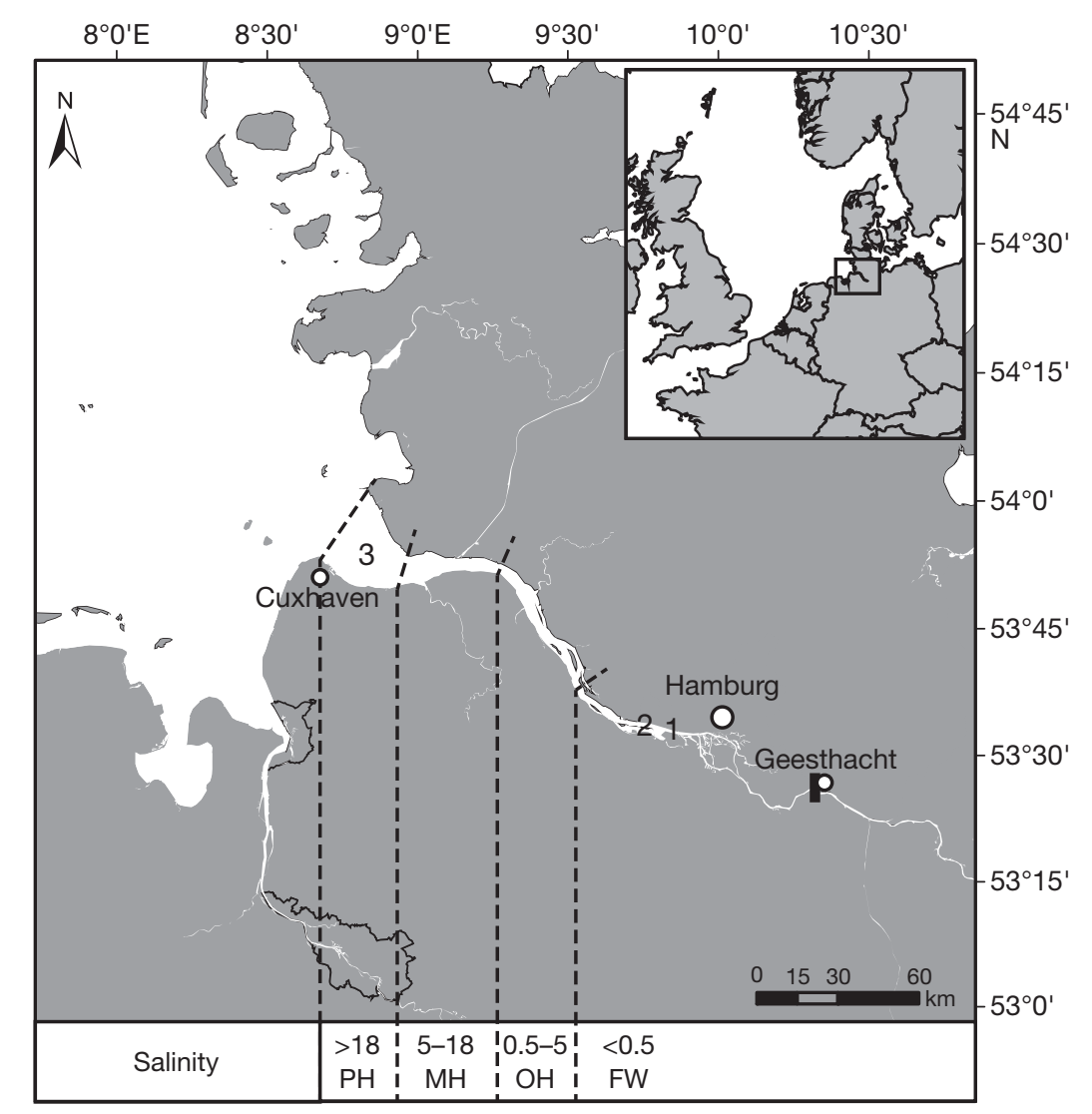

Fig. 1. Study area, showing the North Sea and the Elbe estuary in the German Bight. Freshwater $(\mathrm{FW})$, oligohaline $(\mathrm{OH})$, mesohaline $(\mathrm{MH})$ and polyhaline $(\mathrm{PH})$ sections of the estuary are shown (Stiller 2010). Sampling locations were in the freshwater section close to Hamburg, where 9 (Site 1) and 17 (Site 2) Coregonus maraena individuals were caught. One fish was caught in the polyhaline section of the River Elbe close to Cuxhaven (Site 3). The black bar marks the only migration barrier (weir) in the Elbe estuary 
(BiMES Binnenfischerei, Leezen, Germany), and therefore experienced exclusively pure freshwater conditions over its lifetime, was obtained in July 2013 and served as a control.

After defrosting, total length (TL) and sex of the individuals were determined. Opercula were removed for subsequent age determination. Sagittal otoliths of all individuals were extracted, cleaned with distilled water and air dried. One randomly chosen otolith per individual was used for otolith microchemical analyses. Specifically, thin sections $(0.5 \mathrm{~mm})$ of the otoliths were cut and glued to glass slides with Crystalbond Mounting Wax (Buehler; http://www. buehler.com). These sections were then ground manually using lapping papers of 30, 12 and $3 \mu \mathrm{m}$, consecutively, until the core area could be detected under a light microscope (Leica DM 750). Finally, otoliths were polished using aluminum paste (ALPHA MICROPOLISH 2, grain size $0.3 \mu \mathrm{m}$ ).

\subsection{Laser ablation inductively coupled plasma mass spectrometry (LA-ICP-MS) analysis of otoliths}

Microchemical analyses of otoliths were performed at the Department of Geosciences of Bremen University, Germany, using a NewWave UP193ss solid-state laser with $193 \mathrm{~nm}$ wavelength coupled to a Thermo Element2 ICP mass spectrometer.

Transects were set from the nucleus-area to the edge of each otolith. Like some other salmonids (Kalish 1990), C. maraena possesses not just 1 but 2 core areas in its otoliths. The midpoint between these 2 areas was defined as the nucleus of the otolith and set as the starting point of ablation (Fig. 2). Prior to ablation, the blank signal was recorded for $20 \mathrm{~s}$.

The sample surface was pre-ablated with a spotsize of $75 \mu \mathrm{m}$ and a scan speed of $100 \mu \mathrm{m} \mathrm{s}^{-1}$. For transect ablation, a $50 \mu \mathrm{m}$ spot-size with $3 \mu \mathrm{m} \mathrm{s}^{-1}$ scan speed and a laser pulse rate of $10 \mathrm{~Hz}$ was used. Irradi-

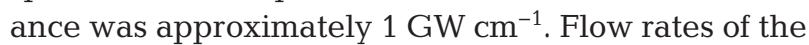
carrier gas (helium) and the make-up gas (argon) were about 0.7 and $0.91 \mathrm{~min}^{-1}$, respectively. The in-

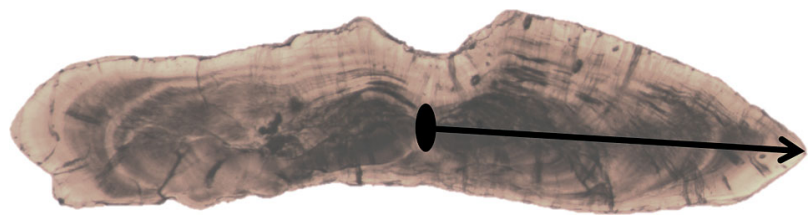

Fig. 2. Thin section of a Coregonus maraena otolith illustrating 2 core areas and the midpoint (black ellipse) defined as the otolith core from which transects (black arrow) were ablated tensities of the isotopes ${ }^{88} \mathrm{Sr},{ }^{43} \mathrm{Ca}$ and ${ }^{143} \mathrm{Ba}$ were measured. A synthetic glass (NIST 610; National Institute of Standards and Technology, Gaithersburg, MD) was used as an external calibration standard and was analyzed after every second transect. A correction for the isobaric interference of double-charged ${ }^{86} \mathrm{Sr}$ on ${ }^{43} \mathrm{Ca}$ was performed based on analyses of the carbonate reference standard MACS-3 (Jochum et al. 2012). Analytical precision and accuracy were assessed by analyzing a pressed pellet of the otolith reference standard NIES CRM No.22 (Yoshinaga et al. 2000) on each measurement day. Precision was around $5 \%$ and accuracy was better than $10 \%$.

As a result of the automated sawing during the otolith preparation process, some otoliths were not perfectly cut in their core region. Thus, the first $150 \mu \mathrm{m}$ of each measured otolith transect was excluded from subsequent analysis.

\subsection{Differentiation between habitats}

Different salinity regimes were identified from the frequency distribution of all $\mathrm{Sr}$ :Ca ratios measured using an approach similar to that of Daverat et al. (2011) and Magath et al. (2013). This approach is theoretically based on the expected multimodality of the frequency because $C$. maraena mainly uses 2 habitats of very different salinity (Wadden Sea as feeding habitat and freshwater for spawning and early life stages, e.g. Jensen et al. 2003). In a first step, a multimodal frequency distribution was plotted with singly measured Sr:Ca ratios of all individuals available. This distribution revealed 1 strong maximum at low Sr:Ca ratios and 2 weak maxima at higher Sr:Ca ratios. In the second step, the first strong maximum was separated from the 2 following weak maxima according to the expected main habitats in freshwater and Wadden Sea, which resulted in the assignment of a lowsalinity ( $\mathrm{Sr}$ :Ca ratios $\leq 0-2.1 \mathrm{mmol} \mathrm{mol}^{-1}$ ) and a highsalinity regime ( $\mathrm{Sr}$ :Ca ratios $>2.1 \mathrm{mmol} \mathrm{mol}^{-1}$, Fig. 3 ).

The established salinity regimes agree well with findings of the closely related C. lavaretus from the Baltic Sea, where sea-spawning individuals had Sr:Ca values $>2.0 \mathrm{mmol} \mathrm{mol}^{-1}$ (Rohtla et al. 2017). Nevertheless, to further validate the approach, we used $\mathrm{Sr}$ :Ca ratios of fish from known salinity origins as reference. The freshwater reference was given by both the Sr:Ca ratios (all measurements) of the freshwater-reared individual which did not originate from the Elbe estuary ('freshwater control') and the last section (last $6 \mathrm{Sr}$ :Ca measurements) of ablated transects of 26 individuals caught in the freshwater part 


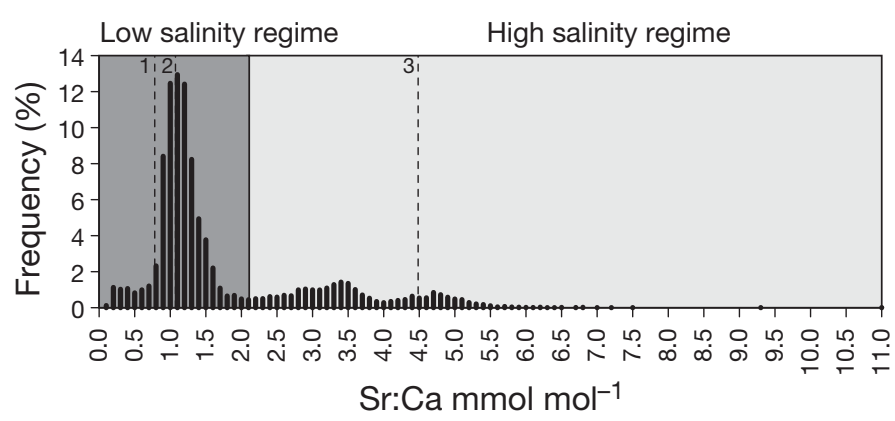

Fig. 3. Frequency distribution of all Coregonus maraena otolith Sr:Ca ratios, showing a low-salinity regime (limnic to slightly brackish water) and a high-salinity regime (medium brackish to euhaline water); numbers refer to reference material, where 1: 'freshwater control,' $0.78 \mathrm{mmol} \mathrm{mol}^{-1}$; 2 'freshwater-caught fish,' $1.07 \mathrm{mmol} \mathrm{mol}^{-1}$; and 3: 'polyhaline water-caught fish,' $4.48 \mathrm{mmol} \mathrm{mol}^{-1}$

of the Elbe estuary, 'freshwater-caught fish', see Fig. 1). Similarly, the last $6 \mathrm{Sr}$ :Ca measurements of the ablated transect of the 1 individual caught in the lower reaches of the Elbe estuary (i.e. in polyhaline waters at the time of capture, 'polyhaline watercaught fish', see Fig. 1) provided the reference values for habitat of higher salinity.

The calculated mean $( \pm \mathrm{SD})$ value for freshwatercaught fish ( $\mathrm{Sr}: \mathrm{Ca}=1.07 \pm 0.44 \mathrm{mmol} \mathrm{mol}{ }^{-1}$ ) was slightly above the mean value of the freshwater control $\left(0.78 \pm 0.07 \mathrm{mmol} \mathrm{mol}{ }^{-1}\right)$ and nearly equaled the strong first peak of the frequency distribution (Fig. 3), indicating that the defined low-salinity regime reflects limnic to slightly brackish waters. In contrast, the average $\mathrm{Sr}$ :Ca ratio of the polyhaline water-caught fish $\left(4.48 \pm 1.03 \mathrm{mmol} \mathrm{mol}^{-1}\right)$ was close to the third peak, thus the high-salinity regime likely reflected medium brackish to euhaline waters.

An inverse relationship between $\mathrm{Sr}: \mathrm{Ca}$ and $\mathrm{Ba}: \mathrm{Ca}$ ratios in the otoliths was observed (rho $=-0.265, \mathrm{p}<$ 0.001), which is well-known from studies on habitat use of migratory fishes along a salinity gradient (Walther et al. 2011).

\subsection{Determination of age and annuli}

For age determination, annuli were counted along each ablated otolith transect from the LA-ICP-MS analysis. For this purpose, these sections were viewed under a light microscope (Leica DM 750) at 40-100× magnification using transmitted light, and possible ring structures were examined. The results were verified by examining opercula, as annuli can be identified more precisely in these hard structures compared to otoliths (Gerson 2013).

\subsection{Data analysis and statistics}

Temporal habitat use and potential movements of fish between the specified habitats (low- and highsalinity regimes) were detected by measured Sr:Ca ratios along the ablation transects. Combined with age chronologies along the transects, this allowed for the reconstruction of individual migration life histories. Specific habitat uses and movements determined in this way were grouped into categories based on similarity (hereafter referred to as 'migration patterns'). Potential differences in the prevalence of these patterns between sexes and with age were then assessed using Fisher's exact test. Shapiro-Wilk tests were performed to test for normality of data. Because all data were not normally distributed, group sizes were unequal and sample size of subsets was small $(<9)$, non-parametric tests were used for further comparisons (e.g. Raine et al. 2020). Correlations between $\mathrm{Sr}: \mathrm{Ca}$ and Ba:Ca ratios as well as age and TL were tested using Spearman's rho statistic. Comparisons of fish size among sexes, age groups and migration strategies were conducted using the Mann-Whitney $U$-test. All statistical analyses were performed using $\mathrm{R}$ version 3.4.0 (R Core Team 2017).

\section{RESULTS}

\subsection{Migration patterns}

The otolith analyses revealed variability in migration behavior of maraena whitefish. Individuals either showed temporal habitat use and movements between the specified habitats (low-salinity regime including freshwater and slightly brackish water habitats and high-salinity regime including medium brackish to euhaline waters) or stayed permanently within the low-salinity regime. The signal profiles resulting from Sr:Ca measurements along the ablation transects were categorized into 3 patterns, as follows.

Pattern 1 was characterized by a one-time temporary increase in $\mathrm{Sr}$ :Ca ratios above the threshold of $2.1 \mathrm{mmol} \mathrm{mol}^{-1}$. Eight individuals $(29.6 \%)$ were assigned to this pattern. Of these, 7 showed a subsequent decrease in $\mathrm{Sr}$ : Ca ratios below the threshold along the transect (Fig. 4a), indicating one migration from a low- to a high-salinity regime, followed by a return into the low-salinity environment. Three individuals showed slight modifications of the underlying signal profile, with 2 individuals (Nos. 2 and 7 in Fig. S1 in the Supplement at www.int-res.com/articles/ 
(a) Pattern $1(\mathrm{~N}=8)$

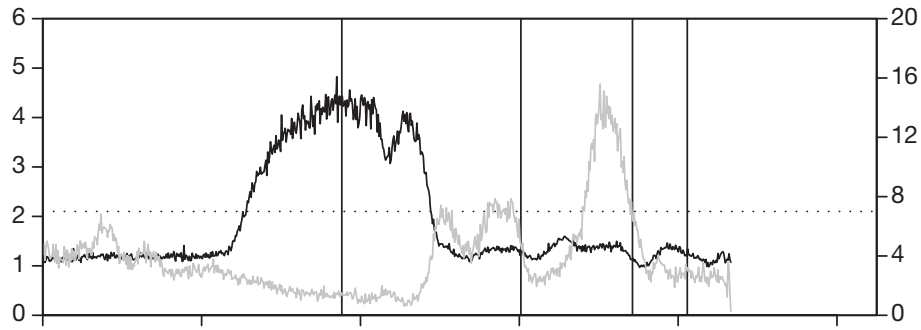

(b) Pattern $2(\mathrm{~N}=4)$

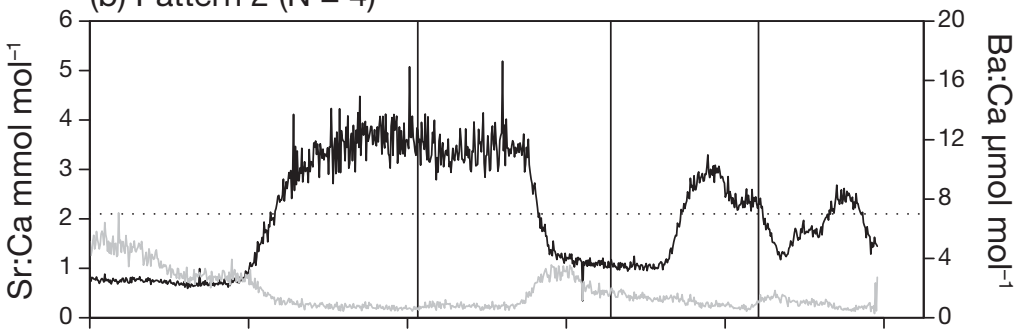

(c) Pattern $3(\mathrm{~N}=15)$

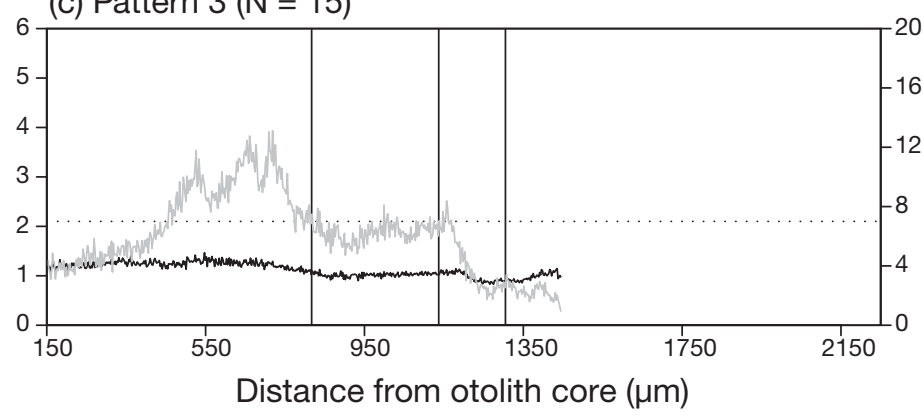

Fig. 4. Exemplary profiles of Sr:Ca ratio (black) and Ba:Ca ratio (gray) measurements along Coregonus maraena otolith transects illustrating (a) one-time migration into the high-salinity regime (pattern 1), (b) multiple migrations into the high-salinity regime (pattern 2) and (c) residency within the low salinity habitat (pattern 3). The dashed horizontal line marks the Sr:Ca threshold between the low- and high-salinity regimes. Vertical lines correspond to annuli
For those fish that were assigned to pattern 1 or 2 and which thus showed at least 1 seaward migration, this behavior occurred early in life (at the age of $0+$ ).

Pattern 3 was defined as a long-term stay, i.e. residency, in the low-salinity regime with no habitat change, and was characterized by a signal curve that remained constantly below the predefined threshold (Fig. 4c). The majority of fish $(15 / 27 ; 55.6 \%)$ displayed this pattern, all of which were sampled in the freshwater section close to Hamburg (see Fig. 1, Sites 1 and 2). Median age of individuals was 2 yr (range 1-8 yr). Unlike in patterns 1 and 2, the value of the correlation coefficient (rho $=0.520, \mathrm{p}<0.001$ ) indicated a positive correlation between $\mathrm{Sr}: \mathrm{Ca}$ and Ba:Ca signal profiles.

\subsection{Migratory behavior and sex}

There was no significant difference between males and females in the relative proportions of migratory (pattern 1 or 2) versus resident (pattern 3 ) migration strategies, with 7 out of 15 assessed females $(47 \%)$ and 5 out of 12 males $(42 \%)$ representing the migratory strategy (Fisher's exact test, $\mathrm{p}>0.05$ ). suppl/n044p263_supp.pdf) that already showed high $\mathrm{Sr}: \mathrm{Ca}$ ratios at the beginning of the measurements, and 1 individual (No. 8 in Fig. S1) for which Sr:Ca ratios remained high and did not decrease to low-salinity values again. Median age of individuals exhibiting pattern 1 was 2 yr, with an age span of 1-4 yr. There was a strong correlation between $\mathrm{Sr}$ :Ca and Ba:Ca ratios (rho $=-0.745, \mathrm{p}<0.001$ ) of all associated individuals, indicating an inverse relationship.

Pattern 2 was characterized by repeated increases in $\mathrm{Sr}$ :Ca ratios above the predefined threshold along the transect (Fig. 4b), indicating several migrations between the 2 environments. Four individuals (14.8\%) represented this pattern, with a median age of $3 \mathrm{yr}$ (range 3-7 yr). An inverse relationship between $\mathrm{Sr}: \mathrm{Ca}$ and $\mathrm{Ba}: \mathrm{Ca}$ ratios was also detected here (rho $=$ $-0.638, \mathrm{p}<0.001)$.

\subsection{Migratory behavior and fish size}

As expected, TL was highly positively correlated with age (Spearman's rho $=0.69$, p $<0.001$ ), so to detect differences in body length between migrating (patterns 1 and 2) and non-migrating (pattern 3) individuals, age needed to be considered. As the majority of individuals had an age of 2 or $3 \mathrm{yr}(\mathrm{N}=22)$, the subsequent analyses considered only these 2 age groups (AGs). There was no significant difference in the TL between sexes for either AG 2 or AG 3, ( $U=$ $34, \mathrm{p}>0.05$ for AG 2, $U=5, \mathrm{p}>0.05$ for AG 3), so males and females were combined. For AG 2, migrating individuals showed significantly higher TL than resident individuals $(U=7, \mathrm{p}<0.05)$ with a median length of $38.1 \mathrm{~cm}$ (range 28.9-40.8 cm) compared to $28.8 \mathrm{~cm}$ (range 25.2-31.9 cm) in resident fish (Fig. 5). 
For AG 3, there was also a trend towards higher body size in migrating individuals (median $37.2 \mathrm{~cm}$, range $37.0-41.6 \mathrm{~cm}$ ) compared to residents (median $32.3 \mathrm{~cm}$, range 30.9-44.2 cm, Fig. 5), but this difference was not statistically significant $(U=3, \mathrm{p}>0.05)$.

\section{DISCUSSION}

After maraena whitefish had almost disappeared from the North Sea as a result of human disturbance, re-introduction programs have aimed to ensure the return of this fish species to its formerly native range including the River Elbe, and ultimately to the establishment of self-sustaining (i.e. supported by natural reproduction) populations. To date, however, these programs have relied on continuous restocking, as appropriate management measures supporting natural population replenishment are still lacking due to the poor knowledge of the biology of this endangered species (Svendsen et al. 2018).

The present study addressed this issue by investigating the habitat use and migration behavior of the reintroduced population of maraena whitefish in the Elbe for the first time. Using otolith microchemistry, 2 fundamentally different migration strategies were found and expressed among individuals ranging from 24.6 to $58.4 \mathrm{~cm}$ in TL (median $31.3 \mathrm{~cm}, \mathrm{SD} 8.4 \mathrm{~cm}$ ) and

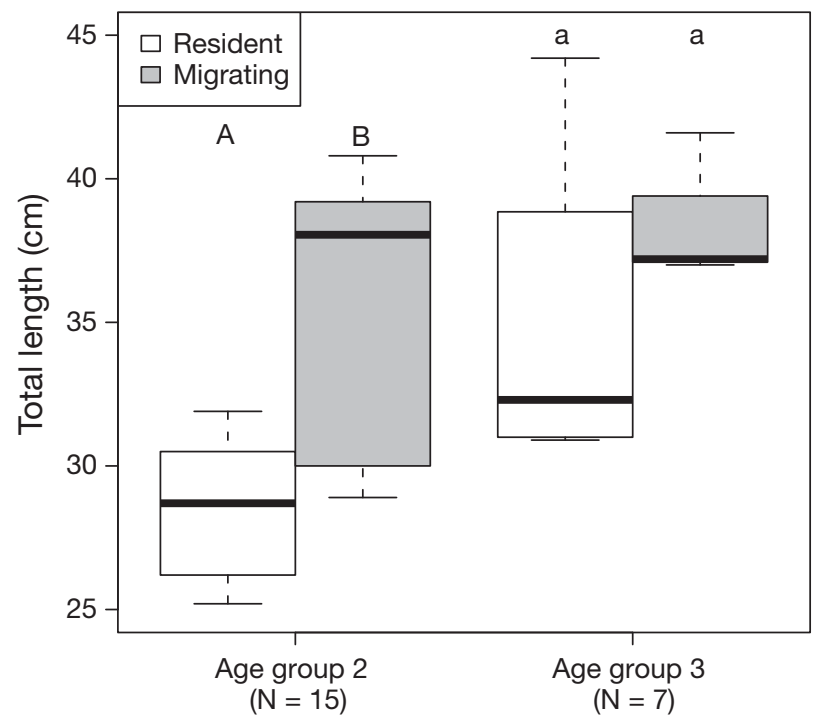

Fig. 5. Comparison of the total length of resident and migrating maraena whitefish of age group (AG) 2 and AG 3. Boxes represent the first and third quartiles, the horizontal line indicates the median, and whiskers extend to the most extreme data points. Within AGs, different letters above the plots indicate significant differences (Mann-Whitney $U$-test $\mathrm{p}<0.05)$ an age of 1 to $8 \mathrm{yr}$ in this population: migration between different salinity regimes or permanent residency in low salinity habitat. This phenomenon, which is known as partial migration of a population (Chapman et al. 2012b), can offer advantages in terms of adaptation to variable environmental conditions, but it also has specific conservation implications, which are discussed further in Section 4.5.

\subsection{Migratory patterns}

The finding of differential migration strategies, with $44 \%$ of the population showing migratory and $56 \%$ exhibiting permanent resident behavior, indicates a high degree of intraspecific variation within the Elbe population of maraena whitefish.

According to Jensen et al. (2003), maraena whitefish from the North Sea reach sexual maturity at the age of 2-3 yr (male) or 3-4 yr (female). Applied to this study, most sampled fish that showed permanent resident behavior were likely to be mature already $(66.67 \%)$. The mean TL of those resident fish was $32.3 \mathrm{~cm}$, ranging from 25.2 to $58.4 \mathrm{~cm}$, and ages ranged from 1 to $8 \mathrm{yr}$. Borcherding et al. (2008) observed the migration behavior of maraena whitefish from the River Rhine and found that some of the sampled fish stayed in freshwater for a relatively long time and migrated when they had reached a TL of about $30-35 \mathrm{~cm}$. Therefore, it cannot be excluded that several of the 15 individuals that presented pattern 3 in the present study (of which 7 were smaller than $30 \mathrm{~cm}$ ) would also have migrated at a later point in time if they had reached a greater body length. However, a larger proportion already migrated in the juvenile stage at a TL of 35-40 mm. L. F. Jensen et al. (2015) also discussed an observation of an earlier study that also showed that juvenile Coregonus maraena of such a small size are already present in saltwater and even actively ingest food there, which indicates improved hyperosmotic tolerance in that early stage of life. In line with this, L. F. Jensen et al. (2015) compared the salinity tolerance of larvae and juvenile C. maraena and found that hyperosmotic tolerance increased with increasing body length. The juvenile $C$. maraena used in their study had a TL of 33-50 $\mathrm{mm}$, indicating that those small fish develop the ability to hypo-osmoregulate and could migrate to higher salinities. In this context, it can be assumed that the non-migrating individuals in our study had already reached a tolerable size for migration long ago; and yet they did not do so. 
This confirms earlier reports showing that populations of migratory fishes can have high migratory plasticity (e.g. Cucherousset et al. 2005, Miller et al. 2010, Magath et al. 2013), some including resident individuals (e.g. Jonsson \& Jonsson 1993, Chapman et al. 2012b, Kendall et al. 2015). The partial migration of $C$. maraena shown here is also known from other coregonids in the northern hemisphere, e.g. C. nasus, C. clupeaformis, C. sardinella and Stenodus leucichthys (Tallman et al. 2002, Howland et al. 2009, Harris et al. 2012). Partial migration to brackish water has also been documented in Baltic Sea populations of European whitefish C. lavaretus, with some populations migrating to spawn in coastal rivers and streams, and others spawning in shallow, low-salinity bays in the northern Baltic Sea (Sõrmus \& Turovski 2003). Moreover, the population from the River Tornionjoki (northern Baltic Sea) shows differential migration behavior in the marine phase, with part of the population staying in the northern Baltic and another part migrating further south to higher-salinity waters (Jokikokko et al. 2018).

Similarly to this study, migratory plasticity was also found in the $C$. maraena population from the Danish River Vidå (Jensen et al. 2018), but here migration behavior mainly differed between relatively large early- and late-migrating individuals (mean \pm SD length $42.7 \pm 6.4 \mathrm{~cm}$ ) and was not characterized by a high degree of residency as identified in the present study. Although in the River Rhine, the majority of analyzed C. maraena were non-migrating (Borcherding et al. 2008), the situation was different from that in the Elbe, as migration barriers (large dams) in the Rhine delta possibly affected the natural migration behavior of $C$. maraena. In contrast, the high proportion of permanent residency in the Elbe, despite the absence of migration barriers, was exceptional and unexpected in the present study.

The development of a non-migrating tendency within an anadromous species may result from several and complex reasons (reviewed by Chapman et al. 2012a) that need to be considered in the context of the complete riverine and estuarine ecosystem. Gross (1987) argued that an anadromous lifestyle is useful when the benefits of more nutritious food in the marine habitat can offset the costs of a long migration into that habitat. Migration behavior reflects a balance between the benefits and cost of migrations that affects the fitness of fish (Jonsson \& Jonsson 1993). The high proportion of permanent residency (i.e. feeding and spawning in the same habitat) in the Elbe in the present study would thus point to comparable net benefits for C. maraena.
In principle, migrations may be motivated by the need to spawn, feed and seek refuge from predators, but human activities may also influence the dynamics of fish migration (Chapman et al. 2012b). In the case of $C$. maraena, migration to feed in the sea but return to spawn is most likely, based on what is known about the life history of the species (Jensen et al. 2018). However, as the number of spawning individuals was not investigated, it is not possible to say conclusively whether or how many spawning migrations were carried out here.

The underlying data suggest that the reasons for migration were already effective very early in life. Specifically, if an individual did not leave the lowsalinity environment in the first year of life, it also did not do so at a later point in time. In contrast, some individuals migrated during the first year of life, returned into the low-salinity environment and became resident thereafter (pattern 1). With a medium age of 2 yr, these individuals were relatively young. Therefore, it is possible that some of them would have migrated again later; also indicated by pattern 2 , which is characterized by multiple migrations and older individuals (median age $3 \mathrm{yr}$ but including 1 individual of $7 \mathrm{yr}$ ) than in pattern 1. Some of them returned to low-salinity environment in the same year of their hatch. This is well before they reach sexual maturity, reported at the age of 2-3 yr (males) or 3-4 yr (females) (Jensen et al. 2003).

In these cases, the migration thus does not represent a spawning migration. Immature maraena whitefish have been monitored in the lower sections of Danish rivers during winter (Jensen et al. 2003). This has also been observed in mature and immature individuals of closely related anadromous salmonids, especially within the genus Salvelinus, such as Arctic charr Salvelinus alpinus, which can return to rivers to overwinter (e.g. Klemetsen et al. 2003, A. J. Jensen et al. 2015). Similar behavior could also be a possible explanation for the early return of the fish examined here. The fact that the individuals assigned to patterns 1 and 2 were already caught in the Elbe in June/July also raises questions regarding contrasting temporal regulation of migration behavior among river systems, since spawning migrations have been observed in late fall in the Rivers Rhine (Borcherding et al. 2014) and Vidå (Hertz et al. 2019).

These observations suggest that living (including feeding) conditions in the Elbe may have been sufficient for C. maraena, possibly because of the low population density favoring residency (Jonsson \& Jonsson 1993). The high residency rate also demon- 
strates that the river system of the Elbe is likely to be of major importance for C. maraena not only as spawning but also as feeding habitat.

So far, it is unknown whether the reasons for the observed partial migration have an underlying phenotypic or genotypic origin. There is evidence that different genotypes as well as hybridizations of coregonids (C. maraena and non-migratory lake whitefish C. lavaretus) coexist in the Elbe (Dierking et al. 2014). C. maraena physiologically differs from C. lavaretus in terms of osmoregulation (Hertz et al. 2019). This is reflected in the ability of C. maraena to tolerate high salinities and undertake migrations into the North Sea, which C. lavaretus is not able to do (Grøn 1987). Studies elucidating a possible genetic basis for differential migration behavior (see e.g. Hess et al. 2016) would be an important future direction to pursue, but such an analysis was beyond the scope of the present study.

\subsection{Irregularities in migration patterns}

Some otoliths in the present study showed high $\mathrm{Sr}$ :Ca ratios, above the defined threshold separating the low- and high-salinity regime, in the innermost (i.e. earliest observed) measurements (Fig. S1, Nos. 2, 7 and 10). The lack of information for the earliest life stage provided by the Sr:Ca signal profile (the first $150 \mu \mathrm{m}$ were removed from each profile) combined with the tendency of a relatively fast downstream migration as observed for stocked juvenile fish of 20-60 mm TL in the Rhine system (Borcherding et al. 2006) could be a significant factor in this observation. Since there is no evidence that reproduction of C. maraena can occur in high-salinity habitats in the North Sea, it can be assumed that these individuals also initially lived in the low-salinity regime. According to Jensen et al. (2003), the physiology of maraena whitefish changes when an individual reaches a total length of $30-40 \mathrm{~mm}$, so it can withstand the move to high-salinity waters from that point on.

In contrast, 2 other otoliths showed high $\mathrm{Sr}: \mathrm{Ca}$ ratios at the end of the profiles (Fig. S1, Nos. 8 and 9). A straightforward reason here may be that these individuals had only recently migrated into the River Elbe, where they were captured and had not spent enough time in low-salinity waters for this to be reflected in the otoliths as correspondingly low $\mathrm{Sr}: \mathrm{Ca}$ ratios. Such a time-delayed response of otolith $\mathrm{Sr}: \mathrm{Ca}$ ratios to Sr variation in the ambient water has been noted in previous studies (e.g. Yokouchi et al. 2011).
The time required to establish the state of equilibrium between Sr content of the otoliths and the surrounding water may not have been reached in these cases. According to Elsdon \& Gillanders (2005), it may take 20 d before an Sr signal, corresponding to a new environment, is fully reflected in otoliths. This time-delayed response may also have biased the data points of reference fish used to validate the differentiation among salinity regimes. Ideally, all reference fish should have originated from salinities under controlled conditions. However, these fish were not available, and results of the multimodal frequency distribution as well as similar findings of Rohtla et al. (2017) suggest that the use of the last 6 data points worked quite well.

The unexpected positive correlation between $\mathrm{Sr}: \mathrm{Ca}$ and $\mathrm{Ba}$ :Ca ratios in resident individuals may be explained by the small range of $\mathrm{Sr}$ : Ca ratios close to the lower bound of measured ratios (0.13-2.09 mmol $\mathrm{mol}^{-1}$ ) compared to the range found in migratory individuals (0.34-11.04 mmol mol $\mathrm{m}^{-1}$ ), which could prevent the identification of a negative correlation. Furthermore, slight variations in the $\mathrm{Sr}$ :Ca ratios within the low-salinity regime probably indicate small-scale migrations within the river system, changes in water temperature, food availability or age-related changes in storage rates (Campana 1999, Secor \& Rooker 2000), which alter the uptake and incorporation of Sr into fish otoliths (Sadovy \& Severin 1992, Bath et al. 2000). However, these effects are weaker than the effects of water salinity on $\mathrm{Sr}$ incorporation into otoliths (Marohn et al. 2009, 2011) and are thus expected to be of minor importance. The salinity in the Elbe estuary changes over the tidal cycle, as tidal currents move a water body between 15 and $20 \mathrm{~km}$ down- and upstream twice a day (Bergemann 1995). This could cause slight variations in salinity at sampling locations and it cannot be ruled out that these variations are also reflected in otolith elemental composition to a minor extent.

$\mathrm{Ba}$ :Ca ratios varied strongly within the measured profiles of resident individuals. Ba uptake into otoliths is mainly driven by its availability in surrounding water (Hüssy et al. 2020) but can also be affected by other environmental factors. Bath et al. (2000) found that e.g. temperature can significantly influence the Sr:Ca ratio of marine fish but has no effect on the incorporation of $\mathrm{Ba}$ into the otoliths. However, other studies reported significant temperature effects on $\mathrm{Ba}$ incorporation into otoliths, e.g. for black bream Acanthopagrus butcheri (Elsdon \& Gillanders 2002) and European eel Anguilla anguilla (Marohn et al. 2011), suggesting species-specific dif- 
ferences of temperature effects on the incorporation of Ba into otoliths. To determine if and to what extent temperature or other potential factors (e.g. growth; Walther et al. 2010) are responsible for the observed Ba fluctuations is notoriously complex and beyond the scope of this study.

\subsection{Migratory behavior in relation to sex}

The lack of differences in migration behavior between sexes in our study contrasted with strong differences observed in many other partially migratory salmonid fish species (Jonsson \& Jonsson 1993, Chapman et al. 2012a, Dodson et al. 2013). Among salmonids, females typically dominate the migratory contingent, e.g. in brown trout Salmo trutta and Atlantic salmon S. salar (Jonsson \& Jonsson 1993, Klemetsen et al. 2003). A reason for female-biased migration may lie in the strong correlation of fecundity and body size; migrating to the highly productive marine environment may increase reproductive success through better growth to a greater extent for females than for males (Gross 1987, Jonsson \& Jonsson 1993, Klemetsen et al. 2003). The similar observations for males and females in our study would be in line with the observed high proportion of permanent residency that pointed to sufficient feeding conditions within the Elbe.

\subsection{Migratory behavior in relation to fish size}

Body size may be an important trait that could have an impact on whether to migrate or not (Chapman et al. 2012a, Dodson et al. 2013). Although information on body size before the time of first migration to a high-salinity regime was not available in the present study, body size of older individuals indicated that migrants were larger than residents, with significant differences in AG 2 and the same trend (but without significant differences) in AG 3. This is consistent with previous observations for different species including coregonids (Mehner \& Kasprzak 2011; reviews by Chapman et al. 2012a and Dodson et al. 2013). In temperate waters, the sea generally offers richer feeding grounds than the freshwater environment. This allows migrants to have a higher growth rate compared to resident individuals, which results in larger body size at the same age (Gross 1987, Jonsson \& Jonsson 1993). Factors such as low population density and good feeding opportunities in the freshwater system that favor residency over migratory behavior (Jonsson \& Jonsson
1993) could also have led to the less pronounced differences in body size between migrants and residents of C. maraena in the Elbe.

\subsection{Implication for conservation measures}

The survival of endangered species directly depends on the availability of suitable habitat (Cooke et al. 2012, Arthington et al. 2016). Understanding habitat needs of such species is therefore critical information to support conservation efforts.

A complex stock structure, which is characterized by both residency and migration behavior, emphasizes the need for a differentiated approach to species-specific needs. Resident individuals do not only use the habitat for spawning but also as a feeding habitat throughout the year. The entire life cycle takes place in a relatively small geographical area, which is therefore of crucial importance for the survival of these individuals. Migratory individuals, on the other hand, also need marine habitats and rely in particular on open migration routes to switch between habitats to complete their life cycle. Consequently, the present study identifies the River Elbe system as a crucial area that is used year-round by an important proportion of the population, and is thus relevant as a feeding, spawning and wintering habitat as well as a migration route for maraena whitefish. From this, a need for year-round protection of the riverine habitat can be derived.

However, the Elbe is exposed to strong human impacts such as canalization, industry and fisheries (Kammerad 2001b, Thiel 2011). Commercial shipping in particular is of great importance (Boehlich \& Strotmann 2008). In this context, deepening of the navigation channel has considerably altered the river, which has not only affected the tidal dynamics of the river, but also its biota, including fishes (Thiel 2011). Further investigations of the species-specific habitat use within the Elbe and the impacts of anthropogenic activities on the quality of these habitats would thus have strong potential to support effective management strategies and improve the protection of this priority fish species in the context of the Habitats Directive.

\subsection{Conclusions}

The partial migration within the $C$. maraena population in the Elbe estuary observed here represents an example of phenotypic plasticity in a fish that pos- 
sibly increases fitness under variable environmental conditions (Jonsson \& Jonsson 1993). The occurrence of migrations between the River Elbe and the Wadden Sea, but also a substantial proportion of permanent or at least long-term freshwater habitat use, provides new knowledge to inform conservation decisions. Specifically, it highlights the importance of the Elbe as both feeding and spawning habitat, but also the importance of maintaining migration corridors and connectivity within the system.

Acknowledgements. We thank the fishermen Walther and Claus Zeeck for providing the samples from the Elbe estuary and Friederike Beußel (Thünen Institute of Sea Fisheries) for preparing thin sections of the otoliths.

\section{LITERATURE CITED}

Arthington AH, Dulvy NK, Gladstone W, Winfield IJ (2016) Fish conservation in freshwater and marine realms: status, threats and management. Aquat Conserv 26: 838-857

Bath GE, Thorrold SR, Jones CM, Campana SE, McLaren JW, Lam JWH (2000) Strontium and barium uptake in aragonitic otoliths of marine fish. Geochim Cosmochim Acta 64:1705-1714

Bergemann M (1995) Die Lage der oberen Brackwassergrenze im Elbeästuar. Dtsch Gewässerkdl Mitt 39: 134-137

Boehlich MJ, Strotmann T (2008) The Elbe estuary. Küste 74:288-306

Borcherding J, Scharbert A, Urbatzka R (2006) Timing of downstream migration and food uptake of juvenile North Sea houting stocked in the lower Rhine and the Lippe (Germany). J Fish Biol 68:1271-1286

*Borcherding J, Pickhardt C, Winter HV, Becker JS (2008) Migration history of North Sea houting (Coregonus oxyrinchus L.) caught in Lake IJsselmeer (The Netherlands) inferred from scale transects of ${ }^{88} \mathrm{Sr}:{ }^{44} \mathrm{Ca}$ ratios. Aquat Sci 70:47-56

* Borcherding J, Heynen M, Jäger-Kleinicke T, Winter HV, Eckmann R (2010) Re-establishment of the North Sea houting in the River Rhine. Fish Manag Ecol 17:291-293

* Borcherding J, Breukelaar AW, Winter HV, König U (2014) Spawning migration and larval drift of anadromous North Sea houting (Coregonus oxyrinchus) in the River IJssel, the Netherlands. Ecol Freshw Fish 23:161-170

Campana SE (1999) Chemistry and composition of fish otoliths: pathways, mechanisms and applications. Mar Ecol Prog Ser 188:263-297

* Campana SE, Neilson JD (1985) Microstructure of fish otoliths. Can J Fish Aquat Sci 42:1014-1032

* Chapman BB, Hulthén K, Brodersen J, Nilsson PA, Skov C, Hansson LA, Brönmark C (2012a) Partial migration in fishes: causes and consequences. J Fish Biol 81:456-478

Chapman BB, Skov C, Hulthén K, Brodersen J, Nilsson PA, Hansson LA, Brönmark C (2012b) Partial migration in fishes: definitions, methodologies and taxonomic distribution. J Fish Biol 81:479-499

Cooke SJ, Paukert C, Hogan Z (2012) Endangered river fish: factors hindering conservation and restoration. Endang Species Res 17:179-191
Cucherousset J, Ombredane D, Charles K, Marchand F, Baglinière JL (2005) A continuum of life history tactics in a brown trout (Salmo trutta) population. Can J Fish Aquat Sci 62:1600-1610

* Daverat F, Martin J, Fablet R, Pécheyran C (2011) Colonisation tactics of three temperate catadromous species, eel Anguilla anguilla, mullet Liza ramada and flounder Plathychty [sic] flesus, revealed by Bayesian multielemental otolith microchemistry approach. Ecol Freshw Fish 20:42-51

de Groot SJ (2002) A review of past and present status of anadromous fish species in the Netherlands: Is restocking the Rhine feasible? Hydrobiologia 478:205-218

de Groot SJ, Nijssen H (1997) The North Sea houting, Coregonus oxyrinchus, back in the Netherlands (Pisces, Salmoniformes, Salmonidae). Bull Zool Mus 16:21-24

* Dierking J, Phelps L, Præbel K, Ramm G and others (2014) Anthropogenic hybridization between endangered migratory and commercially harvested stationary whitefish taxa (Coregonus spp.). Evol Appl 7:1068-1083

* Dodson JJ, Aubin-Horth N, Thériault V, Páez DJ (2013) The evolutionary ecology of alternative migratory tactics in salmonid fishes. Biol Rev Camb Philos Soc 88:602-625

Duncker G, Ladiges W (1960) Die Fische der Nordmark. Kommissionsverlag Cram, de Gruyter \& Co, Hamburg

Elsdon TS, Gillanders BM (2002) Interactive effects of temperature and salinity on otolith chemistry: challenges for determining environmental histories of fish. Can J Fish Aquat Sci 59:1796-1808

Elsdon TS, Gillanders BM (2005) Strontium incorporation into calcified structures: separating the effects of ambient water concentration and exposure time. Mar Ecol Prog Ser 285:233-243

Freyhof J (2011) Coregonus maraena. The IUCN Red List of Threatened Species 2011: e.T135672A4176316. https:// www.iucnredlist.org/species/135672/4176316 (accessed 17 February 2019)

Gerson M (2013) Bestandsstruktur, Wanderverhalten und Nahrungsökologie des Schnäpels (Coregonus maraena) in der Elbe. MSc thesis, University of Hamburg

Grøn P (1987) Saving the North Sea houting. In: Tougaard S, Asbirk S (eds) Proceedings of the $5^{\text {th }}$ International Wadden Sea Symposium, Esbjerg, Denmark, Sep. $29^{\text {th }}-$ Oct. $3^{\text {rd }}, 1986$. National Forest and Nature Agency; Museum of Fishery and Shipping, Esbjerg, p 146-159

Gross MR (1987) Evolution of diadromy in fishes. Am Fish Soc Symp 1:14-25

* Hansen MM, Mensberg KLD, Berg S (1999) Postglacial recolonization patterns and genetic relationships among whitefish (Coregonus sp.) populations in Denmark, inferred from mitochondrial DNA and microsatellite markers. Mol Ecol 8:239-252

* Harris LN, Loewen TN, Reist JD, Halden NM, Babaluk JA, Tallman RF (2012) Migratory variation in Mackenzie River system broad whitefish: insights from otolith strontium distributions. Trans Am Fish Soc 141:1574-1585

Hertz M, Jensen LF, Pertoldi C, Aarestrup K and others (2019) Investigating fish migration, mortality, and physiology to improve conservation planning of anadromous salmonids: a case study on the endangered North Sea houting (Coregonus oxyrinchus). Can J Zool 97:1126-1136

Hess JE, Zendt JS, Matala AR, Narum SR (2016) Genetic basis of adult migration timing in anadromous steelhead discovered through multivariate association testing. Proc R Soc B 283:20153064 
Howland KL, Babaluk JA, Chiperzak D, Tallman RF, Low G (2009) Variability in diadromous behavior of a northern coregonid based on scanning proton microprobe analysis of otolith strontium. Am Fish Soc Symp 69:121-134

Hüssy $\mathrm{K}$, Limburg KE, De Pontual $\mathrm{H}$, Thomas ORB and others (2020) Trace element patterns in otoliths: the role of biomineralization. Rev Fish Sci Aquacult, doi:10.1080/ 23308249.2020.1760204

Jacobsen MW, Hansen MM, Orlando L, Bekkevold D, Bernatchez L, Willerslev E, Gilbert MTP (2012) Mitogenome sequencing reveals shallow evolutionary histories and recent divergence time between morphologically and ecologically distinct European whitefish (Coregonus spp.). Mol Ecol 21:2727-2742

Jensen AJ, Diserud OH, Finstad B, Fiske P, Rikardsen AH, Jonsson B (2015) Between-watershed movements of two anadromous salmonids in the Arctic. Can J Fish Aquat Sci 72:855-863

Jensen AR, Nielsen HT, Ejbye-Ernst M (2003) National management plan for the houting. Ministry of the Environment, Forest and Nature Agency, The County of Sønderjylland and the County of Ribe, Ribe

Jensen LF, Thomsen DS, Madsen SS, Ejbye-Ernst M, Poulsen SB, Svendsen JC (2015) Development of salinity tolerance in the endangered anadromous North Sea houting Coregonus oxyrinchus: implications for conservation measures. Endang Species Res 28:175-186

Jensen LF, Rognon P, Aarestrup K, Bøttcher JW and others (2018) Evidence of cormorant-induced mortality, disparate migration strategies and repeatable circadian rhythm in the endangered North Sea houting (Coregonus oxyrinchus): a telemetry study mapping the postspawning migration. Ecol Freshw Fish 27:672-685

Jepsen N, Deacon M, Koed A (2012) Decline of the North Sea houting: protective measures for an endangered anadromous fish. Endang Species Res 16:77-84

* Jochum KP, Scholz D, Stoll B, Weis U and others (2012) Accurate trace element analysis of speleothems and biogenic calcium carbonates by LA-ICP-MS. Chem Geol 318-319:31-44

Jokikokko E, Hägerstrand H, Lill JO (2018) Short feeding migration associated with a lower mean size of whitefish in the River Tornionjoki, northern Baltic Sea. Fish Manag Ecol 25:261-266

Jonsson B, Jonsson N (1993) Partial migration: niche shift versus sexual maturation in fishes. Rev Fish Biol Fish 3: 348-365

Kalish JM (1990) Use of otolith microchemistry to distinguish the progeny of sympatric anadromous and nonanadromous salmonids. Fish Bull 88:657-666

Kammerad B (2001a) Zur Geschichte des Schnäpelfanges in der Mittelelbe: Teil 1. Fisch Teichwirt 5:176-178

Kammerad B (2001b) Zur Geschichte des Schnäpelfanges in der Mittelelbe: Teil 2. Fisch Teichwirt 6:204-207

*Kendall NW, McMillan JR, Sloat MR, Buehrens TW and others (2015) Anadromy and residency in steelhead and rainbow trout (Oncorhynchus mykiss). Can J Fish Aquat Sci 72:319-342

Klemetsen A, Amundsen PA, Dempson JB, Jonsson B, Jonsson N, O'Connell MF, Mortensen E (2003) Atlantic salmon Salmo salar L., brown trout Salmo trutta L. and Arctic charr Salvelinus alpinus (L.): a review of aspects of their life histories. Ecol Freshw Fish 12:1-59

Kottelat M, Freyhof J (2007) Handbook of European freshwater fishes. Kottelat, Cornol and Freyhof, Berlin
Limburg KE, Waldman JR (2009) Dramatic declines in North Atlantic diadromous fishes. BioScience 59:955-965

* Magath V, Marohn L, Fietzke J, Frische M, Thiel R, Dierking J (2013) Migration behaviour of twaite shad Alosa fallax assessed by otolith $\mathrm{Sr}: \mathrm{Ca}$ and Ba:Ca profiles. J Fish Biol 82:1871-1887

* Marohn L, Prigge E, Zumholz K, Klügel A, Anders H, Hanel $\mathrm{R}$ (2009) Dietary effects on multi-element composition of European eel (Anguilla anguilla) otoliths. Mar Biol 156: 927-933

* Marohn L, Hilge V, Zumholz K, Klügel A, Anders H, Hanel $\mathrm{R}$ (2011) Temperature dependency of element incorporation into European eel (Anguilla anguilla) otoliths. Anal Bioanal Chem 399:2175-2184

Mehner T, Kasprzak P (2011) Partial diel vertical migrations in pelagic fish. J Anim Ecol 80:761-770

* Mehner T, Pohlmann K, Bittner D, Freyhof J (2018) Testing the devil's impact on southern Baltic and North Sea basins whitefish (Coregonus spp.) diversity. BMC Evol Biol 18:208

Miller JA, Gray A, Merz J (2010) Quantifying the contribution of juvenile migratory phenotypes in a population of Chinook salmon Oncorhynchus tshawytscha. Mar Ecol Prog Ser 408:227-240

Nelson JS, Wilson MVH, Grande T (2016) Fishes of the world. John Wiley \& Sons, Hoboken, NJ

Pihl L, Cattrijsee A, Codling I, Mathieson S, McLusky DS, Roberts C (2002) Habitat use by fishes in estuaries and other brackish areas. In: Elliott M, Hemingway KL (eds) Fishes in estuaries. Blackwell Science, Oxford, p 10-53

R Core Team (2017) R: a language and environment for statistical computing. https://www.R-project.org/

Raine AF, Anderson T, Vynne M, Driskill S, Raine H, Adams J (2020) Post-release survival of fallout Newell's shearwater fledglings from a rescue and rehabilitation program on Kaua'i, Hawai'i. Endang Species Res 43:39-50

Rohtla M, Svirgsden R, Verliin A, Rumvolt K and others (2017) Developing novel means for unravelling population structure, provenance and migration patterns of European whitefish Coregonus lavaretus s.l. in the Baltic Sea. Fish Res 187:47-57

Sadovy Y, Severin KP (1992) Trace elements in biogenic aragonite: correlation of body growth rate and strontium levels in the otoliths of the white grunt, Haemulon plumieri (Pisces: Haemulidae). Bull Mar Sci 50:237-257

* Secor DH, Rooker JR (2000) Is otolith strontium a useful scalar of life cycles in estuarine fishes? Fish Res 46:359-371

Sõrmus I, Turovski A (2003) European whitefish, Coregonus lavaretus (L.) s.l., Baltic Sea forms. In: Ojaveer E, Pihu E, Saat $\mathrm{T}$ (eds) Fishes of Estonia. Estonian Acad. Publ., Tallinn, p 121-131

Stiller G (2010) Fortschreibung der Untersuchung zur Überwachung von Veränderungen der Makrophytenbestände unter besonderer Berücksichtigung der Salinität im Bearbeitungsgebiet Tideelbe. Flussgebietsgemeinschaft Elbe, Magdeburg. www.fgg-elbe.de (accessed 24 April 2019)

* Svendsen JC, Alstrup AKO, Jensen LF (2018) World Heritage Site fish faces extinction. Nature 556:174

* Tabouret H, Bareille G, Claverie F, Pécheyran C, Prouzet P, Donard OFX (2010) Simultaneous use of strontium:calcium and barium:calcium ratios in otoliths as markers of habitat: application to the European eel (Anguilla anguilla) in the Adour basin, South West France. Mar Environ Res 70:35-45 
Tallman RF, Abrahams MV, Chudobiak DH (2002) Migration and life history alternatives in a high latitude species, the broad whitefish, Coregonus nasus Pallas. Ecol Freshw Fish 11:101-111

Thiel R (2011) Die Fischfauna europäischer Ästuare: eine Strukturanalyse mit Schwerpunkt Tideelbe. Dölling und Galitz, Munich

Thiel R, Thiel R (2015) Atlas der Fische und Neunaugen Hamburgs. Arteninventar, Ökologie, Verbreitung, Bestand, Rote Liste, Gefährdung und Schutz. Behörde für Stadtentwicklung und Umwelt, Amt für Natur- und Ressourcenschutz, Abteilung Naturschutz, Hamburg

Walther BD, Limburg KE (2012) The use of otolith chemistry to characterize diadromous migrations. J Fish Biol 81: 796-825

Walther BD, Kingsford MJ, O'Callaghan MD, McCulloch

Editorial responsibility: Eduardo Martins,

Vancouver, British Columbia, Canada

Reviewed by: 2 anonymous referees
MT (2010) Interactive effects of ontogeny, food ration and temperature on elemental incorporation in otoliths of a coral reef fish. Environ Biol Fishes 89:441-451

*Walther BD, Dempster T, Letnic M, McCulloch MT, Unsworth RKF (2011) Movements of diadromous fish in large unregulated tropical rivers inferred from geochemical tracers. PLOS ONE 6:e18351

Yokouchi K, Fukuda N, Shirai K, Aoyama J, Daverat F, Tsukamoto K (2011) Time lag of the response on the otolith strontium/calcium ratios of the Japanese eel, Anguilla japonica to changes in strontium/calcium ratios of ambient water. Environ Biol Fishes 92: $469-478$

Yoshinaga J, Nakama A, Morita M, Edmonds JS (2000) Fish otolith reference material for quality assurance of chemical analyses. Mar Chem 69:91-97

Submitted: December 8, 2019

Accepted: December 11, 2020

Proofs received from author(s): March 15, 2021 